\title{
プレキャストコンクリート舗装の温度応力に関 する基礎的検討
}

\author{
西澤辰男 ${ }^{1}$ ・野田悦郎 ${ }^{2}$ ・福田 正 $^{3}$ \\ ${ }^{1}$ 工博 石川工業高等専門学校助教授 環境都市工学科 ( T 929-03 河北郡津幡町北中条) \\ ${ }^{2}$ 日本道路 (株) 技術研究所 主任研究員 ( ( 146 東京都大田区多摩川 2-11-20) \\ ${ }^{3}$ 工博 東北大学教授 大学院情報科学研究科 ( 9980 仙台市青葉区荒巻字青葉)
}

\begin{abstract}
プレキャストコンクリート舖装 (PCCP) の設計にあたっては, 荷重応力とともに温度応力の検討が必要であ る. 本研究においては, 試験施工において実測した温度ひずみを平均成分, そり成分, 非線形成分に分離し, そ れぞれが拘束されることによる温度応力について検討した，その結果，PCCP において，路盤摩摖の拘束によ る温度応力および非線形成分による温度応力は，引張成分としては小さく無視できることが分かった，そり応力 については，接合条件を適切に考虑する路盤モデを用いた FEM によって計算が可能であることを示した。
\end{abstract}

Key Words : precast concrete pavement, thermal stress, warping, FEM analysis

\section{1. まえがき}

プレキャストコンクリート舗装 (Precast Concrete Pavement:PCCP) は通常のコンクリート舗装とは異な り, 工場で製作された 1 辺が $1.0 \sim 2.0 \mathrm{~m}$ の比較的小さ な寸法のコンクリート平板を路盤上に設置して施工さ れたものである．このような PCCP に対する合理的な 設計法は確立されておらず，コンクリート舗装の構造 設計法 ${ }^{1)}$ が準用されている. しかしながら, PCCP の 力学的挙動は通常のコンクリート舗装とはかなり異な るため，その違いについては十分な検討が必要である. 著者らは, 交通荷重に対する PCCP の力学的挙動につ いての検討を行い, コンクリート舗装との違いについ て明らかにした 2).

コンクリート舗装の設計においてもう一つの重要な 問題として温度応力がある. コンクリート舗装の温度 応力は, 水平応力, そり応力および内部応力の $3 つ に$ 分けて考えることができる. 水平応力は, コンクリート 版内の平均温度が変化することによる平面的な伸縮が, 路盤との摩擦や端部におりる拘束によって妨げられる ために生ずる応力である. そり応力は, コンクリート版 の上下面の温度差によるそり変形が, 自重や路盤の作 用によって拘束されるために生ずる応力である.内部 応力は, コンクリート版の深さ方向の温度分布が直線 でないために生ずる応力である。

わが国のコンクリート舗装の設計においては, 実験 結果からそり応力を基本として次式を用いている ${ }^{3)}$.

$$
\sigma_{t}=0.35 \cdot C_{w} \cdot \alpha \cdot E \cdot \Delta t
$$

ここに,

$$
\begin{aligned}
\sigma_{t} & : \text { コンクリート版の温度応力 } \\
C_{w} & : \text { 横目地間隔によって定まる係数 } \\
\alpha & : \text { コンクリートの線膨張係数 } \\
E & : \text { コンクリートの弾性係数 } \\
\Delta t & : \text { コンクリート版上下面の温度差 }
\end{aligned}
$$

$C_{w}$ の值は横目地間隔ごとに表の形で与えられているが, 本研究で対象としている PCCP のような目地間隔 $5 \mathrm{~m}$ 未満に対する值は示されていない，そこで本研究にお いては， 1 䢌が $2 \mathrm{~m}$ 程度の平板を用いた PCCP の温度 応力を算定するために，試験舗装における実測と数值 解析によって検討した。

\section{2. 試験舗装における実測}

\section{(1) 試験舗装}

合材センター構内（新潟県小須戸町）に施工された 試験舗装の平面図と舗装構成を図一1に示す。平板の寸 法は, 厚さ $150 \mathrm{~mm}$, 平面形状が $1000 \times 2000 \mathrm{~mm}$ (Panel C), $2000 \times 2000 \mathrm{~mm}($ Panel B), $2000 \times 3000 \mathrm{~mm}$ (Panel A) の 3 種類を図に示すような形で配置した. 路盤は通 常の厚さ $20 \mathrm{~cm}$ の粒調砕石路盤である.

工場で製作されたコンクリート平板を現場に搬入し， 路盤に所定高さにセットした後，平板と路盤の間にで きる陌間 $(10 \sim 20 \mathrm{~mm})$ にセメントグラウトを注入した. 隣接する平板間には厚さ $10 \mathrm{~mm}$ の成形目地板を挟んで いるだけで，荷重伝達装置は施していない，室内試験 により得られたコンクリートの性状および現場で測定 


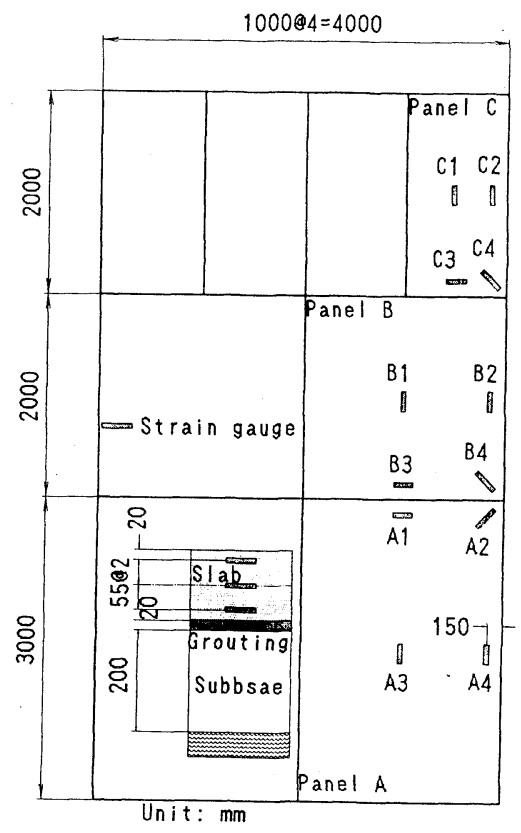

図-1 試験舖装の概要

表-1＼cjkstart実測されたコンクリートの材料および路盤性状

\begin{tabular}{|l||l|}
\hline \hline 項目 & 数値 \\
\hline コンクリートの弾性係数 & $411,000 \mathrm{kgf} / \mathrm{cm}^{2}$ \\
コンクリートのポアソン比 & 0.21 \\
路盤 $k_{30}$ 値 & $24.4 \mathrm{kgf} / \mathrm{cm}^{3}$ \\
\hline \hline
\end{tabular}

された路盤 $k$ 值を表-1に示す.

図-1には主な測定計器の位置も示した. それぞれの パネルの中央部, 縁部, 偶角部, すなわち図中の A1 か らC4 の記号を付した個所に，埋め込みひずみゲージお よび熱電対を厚さ方向の上中下に埋め込んでおいた.

\section{（2）測定}

測定は施工から約一か月経過した時点で, 比較的温 度勾配の大きい初夏（平成 5 年 6 月 16 日）に実施した. 施工後, ダンプトラックによる交通に開放しておいた が, 段差，ひびわれ，過度の目地の開きなどは見られな かった. 16 日午後 2 時から翌日の午後 2 時までの 24 時 間にわたり，30 分ごとにひずみと温度を測定した．図 $-2 \sim 5$ はパネル A の中央部における測定結果である.

図-3のひずみは, 測定時間内において温度勾配が最 小となる時刻 (午前 6 時 3 分) のひずみを 0 として, そ こからの変化量として表している.なお，この時刻にお ける上下面の温度差は $0.1^{\circ} \mathrm{C}$ 程度であり, ほとんど温

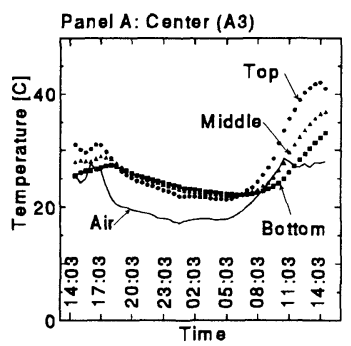

図-2 パネル A の中央部における温度の変化

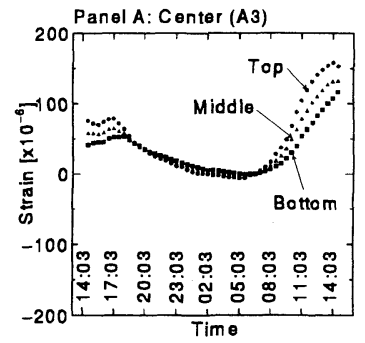

図-3 パネル A の中央部におけるひずみの変化

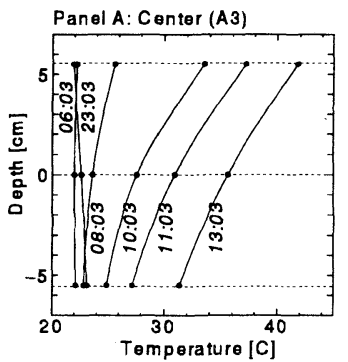

図-4 パネル A の中央部における温度勾配の変化

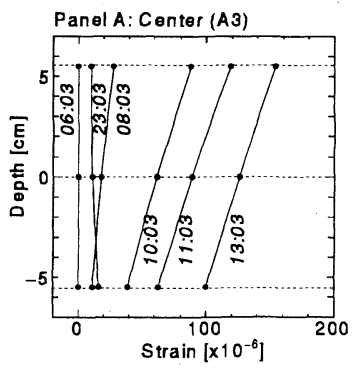

図-5 パネル A の中央部におけるひずみ勾配の変化

度勾配は 0 と考えてよい，平板の温度は日中において 上面部が高く，夜間においては下面部の方がわずかに 高い.今回の測定においては上面部において最高 $43^{\circ} \mathrm{C}$ であり, 平均温度の 1 日の変動幅は約 $16^{\circ} \mathrm{C}$ 程度であっ た. ひずみも温度に伴って変化し，日中上面部が大き く, 夜間は下面部が小さい.ひずみの 1 日の変動量は約 

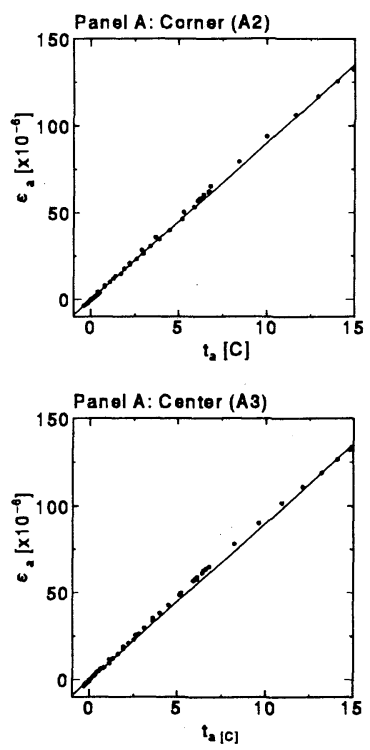
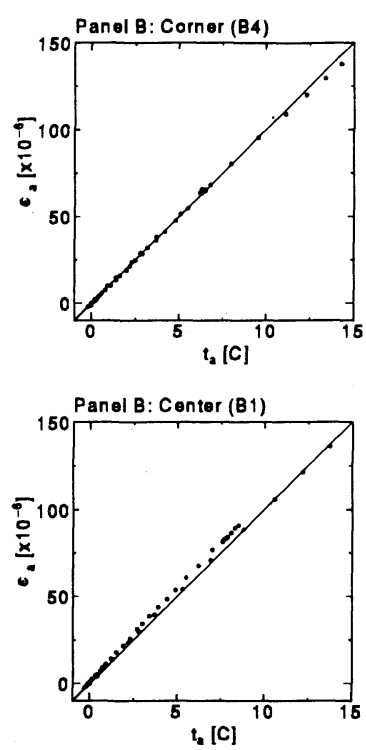
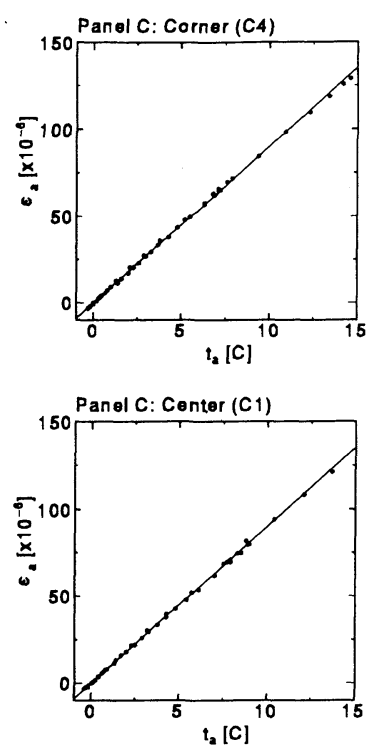

図-7 平板の平均ひずみ $\epsilon_{a}$ と平均温度 $t_{a}$ の関係

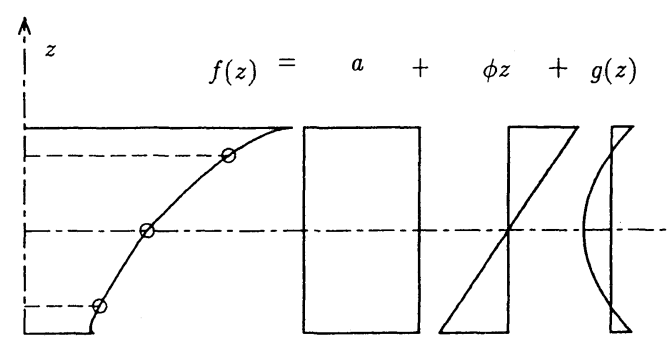

図-6 深さ方向の温度とひずみ分布の分離

$150 \mu$ 程度であった. 図-4および図-5は，それぞれ温度 およびひずみの厚さ方向の分布を示しているが, ほぼ 直線に近いことが分かる.

これらすべてのデータを深さ $z$ 方向について，平均成 分, そり成分および非線形成分に分離して整理するこ とにした.すなわち，深さ分布を次式のように表す.

$$
f(z)=a+\phi z+g(z)
$$

ここに,

$$
\begin{aligned}
f(z) & : \text { 温度あるいはひずみの深さ方向の分布 } \\
a & : \text { 平均成分 } \\
\phi & : \text { 深さ方向の勾配 } \\
g(z) & : \text { 非線形成分 }
\end{aligned}
$$

そこで, 実測值を深さ方向の 2 次式で近似し，平均 成分とそり成分の和を 1 次式で近似することにする. 2 次式の 3 つの係数は平板の上中下に埋め込まれた計器 の実測值から決定した. また, 1 次式の 2 つの係数は以
下の条件より決定した.

$$
\begin{gathered}
\int_{-h / 2}^{h / 2} g(z) d z=\int_{-h / 2}^{h / 2} f(z)-(a+\phi z) d z=0 \\
\int_{-h / 2}^{h / 2} g(z) z d z=\int_{-h / 2}^{h / 2}\{f(z)-(a+\phi z)\} z d z=0
\end{gathered}
$$

\section{3. 平均ひずみ}

\section{（1）水平応力の算定法}

水平応力は, 温度変化によって生ずる自由ひずみか ら実際に生じたひずみを引いた拘束ひずみに弾性係数 を乗ずることによって算定する．拘束の度合いは，自 由ひずみから実測ひずみを引いた值を，自由ひずみで 割った值として表すことができる。

\section{(2) 実測值による検討}

図-7は，平板の平均ひずみ $\epsilon_{a}$ と平均温度 $t_{a}$ の関係で ある.この図においては，平均ひずみおよび平均温度と もに, 温度勾配がほぼ 0 となった午前 6 時 3 分におけ る值からの変化量をプロットしている. それぞれのパ ネルについて左から $\mathrm{A}, \mathrm{B}, \mathrm{C}$ の順に，隅角部における 実測值を上段に，中央部における実測值を下段にまと めて示した，本試験舗装の隅角部においては端部の拘 束がないので，ここでのひずみは自由ひずみと考えて よい，したがって，それぞれのパネルの隅角部における これらの実測值の傾きからコンクリートの線膨張係数 $\alpha$ を算定することができる. それらの值はパネル $\mathrm{A}, \mathrm{B}$ 


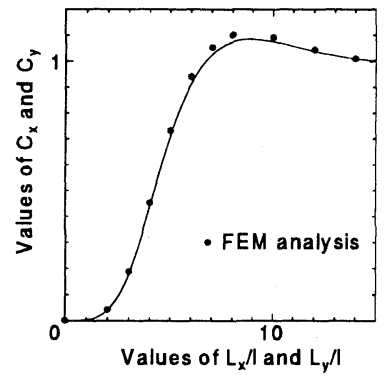

図-8 Bradbury によるそり拘束係数

およびCにおいてそれぞれ， 9,10 および $9 \times 10^{-6} /{ }^{\circ} \mathrm{C}$ であった．図中の直線はこれらの值を用いて計算した 自由ひずみである.

中央部で実測されたひずみがほとんどこの直線に載っ ていることから，今回用いた平板において水平方向の 拘束はほとんどないということがいえる.したがって, $15^{\circ} \mathrm{C}$ 程度の温度変化の場合には目地の影響はなく, 路 盤との摩擦による影響も無視できる.

\section{4. そりひずみ}

\section{(1) そり応力の算定法}

そり応力については, Bradbury が, Westergaard の 考え方に基づいた Winkler 路盤上の弾性平板のモデル を用いて理論計算を行い，次式を提案している ${ }^{4)}$.

- 自由縁部に対して:

$$
\sigma_{\phi}=\frac{C E \alpha t_{\phi}}{2}
$$

- 中央部に対して:

$$
\sigma_{\phi}=\frac{E \alpha t_{\phi}}{2}\left(\frac{C_{x}+\mu C_{y}}{1-\nu^{2}}\right)
$$

ここに,

$$
\begin{aligned}
\sigma_{\phi} & : \text { そり応力 } \\
C, C_{x}, C_{y} & : \text { 境界条件により定まる係数 } \\
\nu & : \text { コンクリートのポアソン比 } \\
t_{\phi} & =\phi_{t} \cdot h: \text { 上下面の温度差 } \\
\phi_{t} & : \text { 厚さ方向の温度勾配 } \\
h & : \text { 版厚 }
\end{aligned}
$$

係数 $C, C_{x}, C_{y}$ は, 図-8によってコンクリート版の幅 $L_{x}$, 長さ $L_{y}$ および剛比半径 から求めることができる. ここに, $l=\sqrt[4]{E h^{3} / 12 /\left(1-\nu^{2}\right) / k}$ である.

一方，平板モデルを用いた数值計算法である FEM に よってもそり応力を計算することができる，そのとき の剛性方程式は次式となる ${ }^{5), 6)}$.

$$
(\mathbf{K}+\mathbf{H}) \cdot \mathbf{d}_{e}=\mathbf{f}_{s}+\mathbf{f}_{v}-\mathbf{H} \cdot \mathbf{d}_{t}
$$

ここに,

$$
\begin{aligned}
\mathbf{K} & : \text { コンクリート版の剛性マトリックス } \\
\mathrm{d}_{e} & : \text { 節点変位ベクトル } \\
\mathbf{f}_{s} & : \text { 交通荷重ベクトル } \\
\mathbf{f}_{v} & : \text { 自重ベクトル } \\
\mathbf{d}_{t} & : \text { そり変形ベクトル } \\
\mathbf{H} & : \text { 路盤の剛性マトリックス }
\end{aligned}
$$

$\mathrm{d}_{t}$ は, i 節点においては次のようになる.

$$
\mathbf{d}_{t i}=\left\{\begin{array}{c}
w_{t i} \\
\theta_{x t i} \\
\theta_{y t i}
\end{array}\right\}=\left\{\begin{array}{c}
w_{t i} \\
-\frac{\partial w_{t i}}{\partial y} \\
\frac{\partial w_{t i}}{\partial x}
\end{array}\right\}
$$

また温度勾配によるそり変形は次式で計算できる。

$$
w_{t i}=-\frac{3 M_{t}}{4 h^{3} E}\left(x_{i}^{2}+y_{i}^{2}\right)
$$

ここに,

$$
\begin{aligned}
M_{t} & =\alpha E \int_{-h / 2}^{h / 2} t(z) d z \\
z & : \quad \text { 平版内の厚さ方向の座標 } \\
t(z) & : \text { 平版内の厚さ方向の温度分布 } \\
x_{i} & : \quad i \text { 節点の } \mathrm{x} \text { 座標 } \\
y_{i} & : \quad i \text { 節点の } \mathrm{y} \text { 版標 }
\end{aligned}
$$

このとき，路盤との接合条件として 2 つの考え方が ある. 一つは路盤と平板が完全に接合されており, たと え平板が路盤から持ち上がったとしても平板と路盤は 接合されたままであるというもので，本研究において はモデル 1 と呼ぶことにする. 他の一つは，平板が路 盤から持ち上がったら，その部分の接合はないと考元 るものであり，モデル 2 と呼ぶことにする.

モデル 1 は取扱いが容易であり, Bradbury の解析 においてもこの考え方に基づいている．モデル 2 の場 合, 剛性方程式が非線形になるため, 繰り返し計算が 必要になる. 本研究においては, 非線形方程式を解くア ルゴリズムとして Newton-Raphson 法を採用しており， $3 \sim 5$ 回の繰り返しで解を得ることができる. 図-8には, Bradbury と同様の路盤モデルを用い FEMによって計 算した拘束係数の值をプロットした．理論的前提が同 一なので, 当然のことながらよく一致している. 本研究 においては，グラウトによる路盤と平板との接合を考 慮するために 2 つのモデルを想定することにした．し たがって，そり拘束ひずみの計算にこれらのモデルを 取り扱うことができるFEM を用いた。

\section{(2) 実測值による検討}

図-9は上下面のひずみ差 $\epsilon_{\phi}$ と温度差 $t_{\phi}$ の関係を, そ れぞれのパネルの中央部, 縁部について示したもので ある. 図は左からパネル A，B および C, 上段から中央 部, 長辺縁部および短辺縁部の順にまとめてある. 隅角 部においてはほとんど拘束の影響がなかったため,こ 

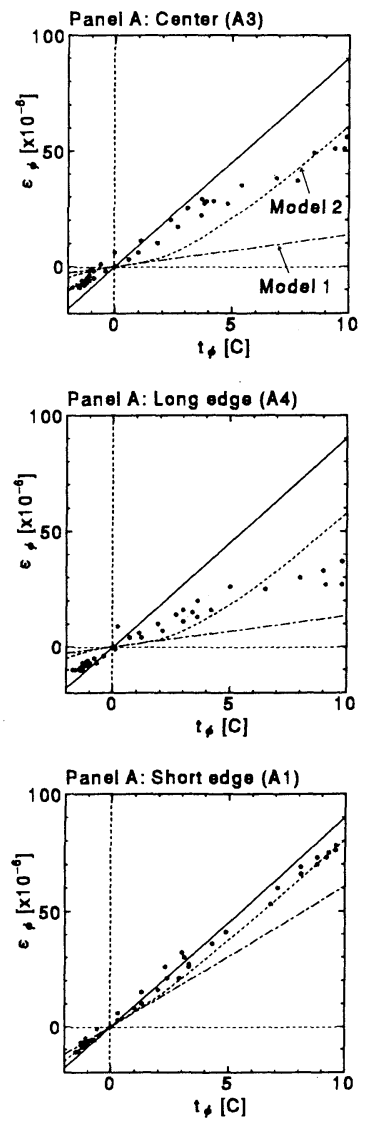
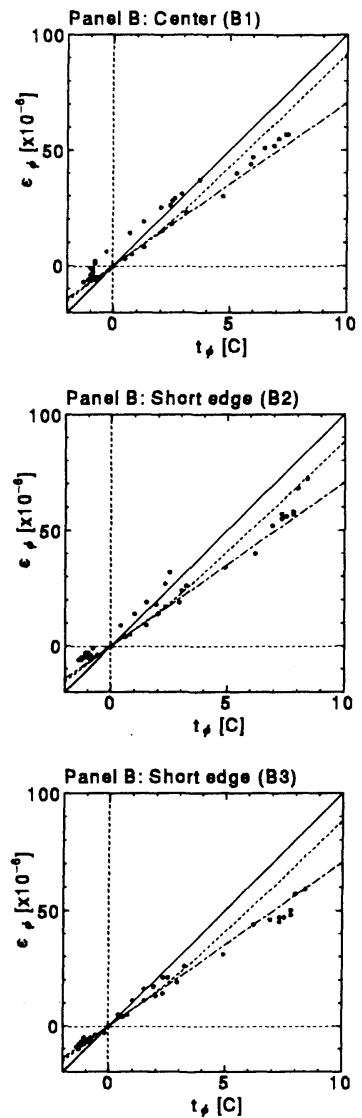
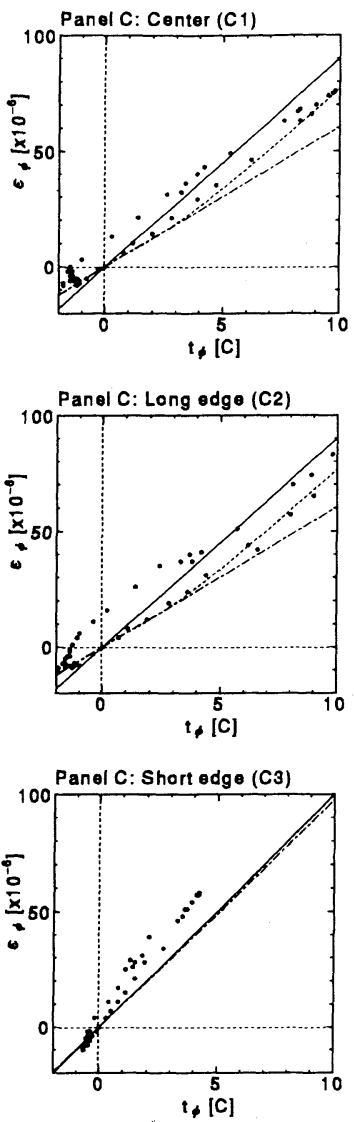

図-9 平板の上下面ひずみ差 $\epsilon_{\phi}$ と温度差 $t_{\phi}$ の関係

こではそれらの結果は省略した．図中の直線は先に求 めたコンクリートの線膨張係数を用いて算定した自由 ひずみである.

そりの場合，実測ひずみが自由ひずみよりも小さな 值を示しており，そり変形が拘束されていることが分か る. 図中の一点鎖線および点線はFEM による計算值で あり，それぞれ平板が持ち上がったときに路盤との接合 を切らない場合 (モデル 1) と切った場合 (モデル 2) の ものであることを示している. FEM の計算にあたって は，実測された表 -1 の值を入力值とし， $100 \times 100 \mathrm{~mm}$ の要素を用いた。

パネル A の場合, 実測值は 2 つのモデルの計算值の 中間にあり, 中央部および短辺縁部はややモデル 2 の 計算値に近く, 長辺縁部はモデル 1 の計算值に近くなっ ている. パネル B の場合, 温度差が小さい領域におい ては測定值がややばらついているが，モデル 1 の計算 值とよく一致している. パネル C の場合, 全体的に実 測值にばらつきが大きくあまり明確なことはいえない が, 短辺縁部を除くとモデル 2 の計算值にほぼ対応し ているといえる。
表-2 PCCP のそり応力

\begin{tabular}{|c|c|r|r|r|}
\hline \hline パネル & モデル & 中央部 & 長牣縁部 & 短辺縁部 \\
\hline $\mathrm{A}$ & 1 & 17.0 & 16.1 & 5.5 \\
$\mathrm{~A}$ & 2 & 7.9 & 8.4 & 2.5 \\
$\mathrm{~B}$ & 1 & 7.0 & 6.0 & 6.0 \\
$\mathrm{~B}$ & 2 & 2.6 & 3.0 & 3.0 \\
$\mathrm{C}$ & 1 & 6.4 & 5.9 & 0.2 \\
$\mathrm{C}$ & 2 & 3.4 & 3.5 & 0.1 \\
\hline \hline
\end{tabular}

FEM によってそれぞれのパネルのそり拘束応力を計 算した結果が表-2である. モデル 1 を仮定した場合, 中 央部にあっては平板の大きさが大きいほど, 縁部にあっ ては辺の長さが長いほど拘束が大きいため応力も大き くなっている. モデル 2 の場合には, 必ずしもそのよ うな傾向にはなっておらず，パネル C の長辺方向の応 力がパネル B の応力よりも大きくなっている.このよ うな場合には平板の形状の影響が大きく, 細長い平板 においては応力の発生が長辺方向に片寄るためである. 

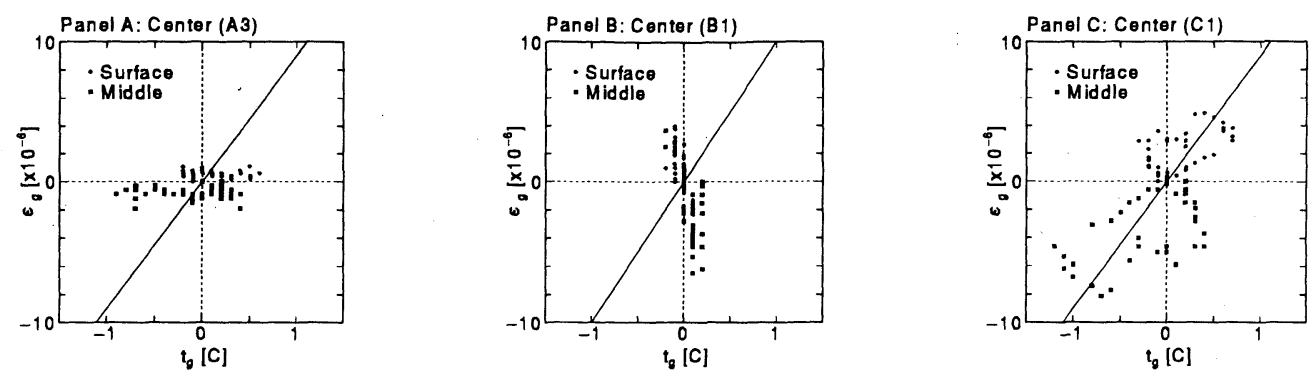

図-10 ひずみの非線形成分 $\epsilon_{g}$ と温度差の非線形成分 $t_{g}$ の関係
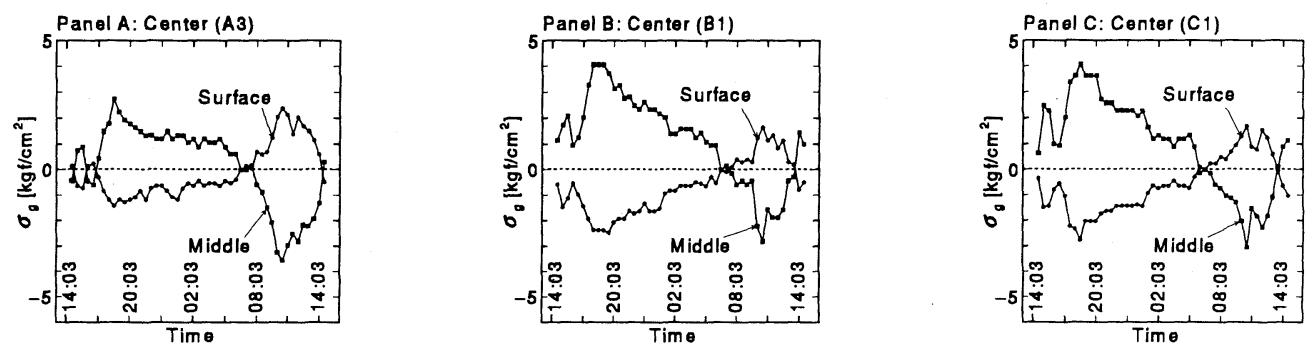

図-11 内部応力 $\sigma_{g}$ の時間的変化

\section{5. 内部ひずみ}

\section{（1）内部応力の算定}

内部応力は, 厚さ方向の温度分布が線形でないこと から生ずる応力であり, 次式によって計算される.

$$
\sigma_{g}=\frac{\alpha E}{1-\nu} t_{g}
$$

ここに,

$$
\begin{array}{ll}
\sigma_{g}: \text { 内部応力 } \\
t_{g}: \text { 温度の非線形成分 }
\end{array}
$$

次項でみるように実際にはひずみにも非線形成分が存 在し, 自由ひずみからその成分を引いた拘束ひずみか ら応力を算定しなくてはならない.

\section{(2) 実測値による検討}

図-10は, 温度の非線形成分 $t_{g}$ とひずみの非線形成 分 $\epsilon_{g}$ の関係を示したものである. 黒丸は表面部, 四角は 中立面の実測值を示している. 本来, 平面保持の仮定 の下ではこのようなひずみは現れないが，実測すると 図にあるように最大 $8 \mu$ 程度生じている. 図中の直線は 先に求めたコンクリートの線膨張係数から計算される 自由ひずみである. 実測值はこの直線に載っておらず, 実測されたひずみは自由ひずみではないことが分かる。 また, $t_{g}$ と $\epsilon_{g}$ の間に明瞭な関係は認められない.

そこで, 自由ひずみから実測ひずみの非線形成分を 引いた拘束ひずみから内部応力を計算し，その時間的 変化を示したのが図-11である. 表面部においては，日 中にはやや大きな引張応力となるが，その值は最大で
も $3 \mathrm{kgf} / \mathrm{cm}^{2}$ とそれほど大きくない，中立面においては， 夜間に $4 \mathrm{kgf} / \mathrm{cm}^{2}$ とやや大きな引張応力が生ずる.

以上の結果より, 今回の試験舗装に用いた寸法の平 板であれば，設計上問題となる表面部の引張応力はわ ずかであり，内部応力は無視してもよいといえる.

\section{6. まとめ}

本研究においてはPCCP の温度ひずみについて，試 験舗装における実測と FEM 解析によって検討を行っ た，実測された温度およびひずみを，平均成分，そり 成分および非線形成分に分け，それらの拘束による温 度応力について検討した，その結果，水平拘束ひずみ および内部ひずみは小さく，設計においては水平応力 および内部応力は無視してよいことが分かった. 一方, そり拘束ひずみは他の拘束ひずみに比べてかなり大き く設計上問題となるが, 適切な路盤との接合条件を用 いた FEM によって算定することができる.

本研究において PCCP の温度応力に関する基本的な 特性は明らかになったと思われる，PCCP を重交通舗 装に適用するためには，供用に伴う平坦性の変化など の舗装としての機能的な要素に関する研究をさらに進 
める必要がある.

\section{参考文献}

1）日本道路協会: セメントコンクリート舖装要綱, 丸善, 1992.

2）西澤辰男, 野田悦郎, 福田正: プレキャストコンクリー 卜舖装の力学的特性に関する基礎的検討, 土木学会論 文集, No.496/V-24, pp.81-88, 1994.

3) 岩間 滋: コンクリート舖装の構造設計に関する実験 的研究, 土木研究所報告, 第 112 号, 1962 .
4) Yoder, E.J. and Witczak, M.W.: Principles of Pavement Design, 2nd ed., John Wiley and Sons, Inc., New York, 1975.

5) 西澤辰男: コンクリート舖装版のそり応力に関する研究, 土木学会中部支部研究発表会講演概要集, V-38, 1993.

6) 蛭川 明, 西澤辰男, 福田 正: そり変形を受けたコン クリート舖装版の荷重応力に関する検討, 土木学会第 48 回年次学術講演会概要集, V-443, 1993.

(1994.4.11 受付)

\title{
A FUNDAMENTAL EXAMINATION OF THE THERMAL STRESS OF PRECAST CONCRETE PAVEMENTS
}

\author{
Tatsuo NISHIZAWA, Etsuro NODA and Tadasi FUKUDA
}

In this paper, the thermal stress of precast concrete pavement (PCCP) is discussed based on the experiment and FEM analysis. The thermal strains measured in the test pavement were divided into three components; axial, warping and nonlinear components, and examined by FEM. Axial and nonlinear components were small in the term of tensile stress, and could be neglected in the structural design. On the other hand, warping component was found to be significant and could be estimated by FEM with appropriate subbase model. 